\title{
Single Flexible Nanofiber to Simultaneously Realize Electricity-Magnetism Bifunctionality
}

\author{
Ming Yang ${ }^{a}$, Shujuan Sheng ${ }^{a}$, Qianli Ma ${ }^{a}$, Nan Lv ${ }^{a}$, Wensheng $Y u^{a *}$, Jinxian Wang \\ Xiangting Dong ${ }^{a * *}$, Guixia Liu ${ }^{a}$ \\ ${ }^{a}$ Key Laboratory of Applied Chemistry and Nanotechnology at Universities of Jilin Province, \\ Changchun University of Science and Technology, Changchun, 130022, China
}

Received: February 20, 2015; Revised: December 9, 2015; Accepted: December 16, 2015

\begin{abstract}
In order to develop new-typed multifunctional composite nanofibers, $\mathrm{PANI} / \mathrm{Fe}_{3} \mathrm{O}_{4} / \mathrm{PVP}$ flexible bifunctional composite nanofibers with simultaneous electrical conduction and magnetism have been successfully fabricated via a facile electrospinning technology. Polyvinyl pyrrolidone (PVP) is used as a matrix to construct composite nanofibers containing different amounts of polyaniline (PANI) and $\mathrm{Fe}_{3} \mathrm{O}_{4}$ nanoparticles (NPs). The bifunctional composite nanofibers simultaneously possess excellent electrical conductivity and magnetic properties. The electrical conductivity reaches up to the order of $10^{-3} \mathrm{~S} \cdot \mathrm{cm}^{-1}$. The electrical conductivity and saturation magnetization of the composite nanofibers can be respectively tuned by adding various amounts of PANI and $\mathrm{Fe}_{3} \mathrm{O}_{4} \mathrm{NPs}$. The obtained electricity-magnetism bifunctional composite nanofibers are expected to possess many potential applications in areas such as electromagnetic interference shielding, special coating, microwave absorption, molecular electronics and future nanomechanics. More importantly, the design concept and construct technique are of universal significance to fabricate other bifunctional one-dimensional nanostructures.
\end{abstract}

Keywords: Electrical conductivity, Magnetism, Polyaniline, Electrospinning, Nanofibers

\section{Introduction}

Electrospinning is an outstanding technique to process viscous solutions or melts into continuous fibers with diameters ranging from micrometer to submicron or nanometer. This technique attracts extensive academic investigations ${ }^{1-3}$ and is also applied in many areas such as filtration, ${ }^{4}$ optical and chemical sensors, ${ }^{5}$ biological scaffolds $^{6}$ and electrode materials. ${ }^{7}$

PANI is one of the most important conducting polymers because of its high electrical conductivity, good redox reversibility, processibility, and environmental stability ${ }^{8,9}$ as well as its a variety of potential applications. ${ }^{9,10}$ In recent years, one-dimensional (1D) structures of PANI including nanowires, rods and tubes have been studied with the expectation that such materials will combine the advantages of both low-dimensional systems and organic conductors. ${ }^{11}$ Sub-micron fibers of pure PANI doped with sulfuric acid or hydrochloric acid were prepared by electrospinning PANI with suitable molecular weight dissolved in hot sulfuric acid, ${ }^{12}$ but it remains a great challenge to apply electrospinning to PANI as limited by its molecular weight and solubility. To overcome this problem, most of the researchers electrospun PANI through blending it with other spinnable polymers. ${ }^{13,14}$

Magnetic $\mathrm{Fe}_{3} \mathrm{O}_{4}$ nanocrystals have been extensively studied owing to their unique and tunable magnetic properties. Their magnetic features have found widespread uses in

e-mail: *wenshengyu2009@sina.com,**dongxiangting888@163.com applications as diverse as environmental remediation, magnetic recording, biomacromolecule separation, catalyst separation, drug/gene delivery and release, and magnetic resonance imaging. ${ }^{15-18}$

In the past few years, multifunctional composite materials have attracted inevasible attention of scientists. ${ }^{19-21}$ Some preparations of $\mathrm{Fe}_{3} \mathrm{O}_{4} @ \mathrm{RE}$ complex ( $\mathrm{RE}=$ rare earth) core-shell structure NPs have been reported. ${ }^{22-24}$ Recently, Ma, et al. have prepared $\mathrm{Fe}_{3} \mathrm{O}_{4} / \mathrm{RE}$ complex magnetic-fluorescent bifunctional composite nanofibers and nanobelts via electrospinning process. ${ }^{25-29}$ Wang et al., have prepared PANI particles/rare earth complex/PVP luminescent-electrical bifunctional composite nanofibers via electrospinning process. ${ }^{30}$ It is found from the above discussion that multifunctional composite materials have attracted extensive academic researches and become one of the popular subjects of study in materials science. To the best of our knowledge, there have been rare reports on the preparation and performance of electricity-magnetism bifunctional nanofibers in the literature.

In the present study, we successfully assembled electricity-magnetism bifunction into single PANI/ $\mathrm{Fe}_{3} \mathrm{O}_{4} / \mathrm{PVP}$ flexible nanofiber via a facile electrospinning technique using PANI as a conductive polymer and $\mathrm{Fe}_{3} \mathrm{O}_{4}$ $\mathrm{NPs}$ as a magnetic material. The structure, morphology and performances of the bifunctional flexible nanofibers were systematically studied, and some new results were obtained. 


\section{Experimental}

\subsection{Chemicals}

Polyvinyl pyrrolidone (PVP, Mw $\approx 90,000)$ and dimethylformamide (DMF) were bought from Tianjin Tiantai Fine Chemical Co., Ltd. Anhydrous ethanol, aniline (ANI), $\mathrm{FeCl}_{3} \cdot 6 \mathrm{H}_{2} \mathrm{O}, \mathrm{FeSO}_{4} \cdot 7 \mathrm{H}_{2} \mathrm{O}, \mathrm{NH}_{4} \mathrm{NO}_{3}$, polyethyleneglycol (PEG, Mw $\approx 20,000)$, ammonia and (IS)-(+)-Camphor-10 sulfonic acid (CSA) were bought from Sinopharm Chemical Reagent Co., Ltd. Ammonium persulfate (APS) was purchased from Guangdong Xilong Chemical Co., Ltd. All the reagents were of analytical grade and directly used as received without further purification. Deionized water was homemade.

\subsection{Preparation of $\mathrm{Fe}_{3} \mathrm{O}_{4} \mathrm{NPS}$}

$\mathrm{Fe}_{3} \mathrm{O}_{4}$ NPs were obtained via a facile coprecipitation synthetic method, and PEG was used as a protective agent to prevent the particles from aggregation. One typical synthetic procedure was as follows: $5.4060 \mathrm{~g}$ of $\mathrm{FeCl}_{3} \cdot 6 \mathrm{H}_{2} \mathrm{O}$, $2.7800 \mathrm{~g}$ of $\mathrm{FeSO}_{4} \cdot 7 \mathrm{H}_{2} \mathrm{O}, 4.04 \mathrm{~g}$ of $\mathrm{NH}_{4} \mathrm{NO}_{3}$ and $1.9 \mathrm{~g}$ of PEG were added into $100 \mathrm{~mL}$ of deionized water to form uniform solution under vigorous mechanical stirring $\left(400 \mathrm{r} \cdot \mathrm{min}^{-1}\right)$ at $50{ }^{\circ} \mathrm{C}$. To prevent the oxidation of $\mathrm{Fe}^{2+}$, the reactive mixture was kept under argon atmosphere. After the mixture had been bubbled with argon for $30 \mathrm{~min}$, $0.1 \mathrm{~mol} \cdot \mathrm{L}^{-1}$ of $\mathrm{NH}_{3} \cdot \mathrm{H}_{2} \mathrm{O}$ was dropwise added into the mixture to adjust the $\mathrm{pH}$ value above 11 . Then the system was continuously bubbled with argon for $20 \mathrm{~min}$ at $50^{\circ} \mathrm{C}$, and black precipitates were formed. The precipitates were collected from the solution by magnetic separation, washed with deionized water for three times, and then dried in an electric vacuum oven at $60^{\circ} \mathrm{C}$ for $12 \mathrm{~h}$ with the vacuum degree of $0.08 \mathrm{MPa}$.

\subsection{Fabrication of electricity-magnetism bifunctional composite nanofibers via electrospinning}

In the preparation of spinning solution, the masses of ANI and $\mathrm{Fe}_{3} \mathrm{O}_{4}$ NPs were respectively proportional to the mass of PVP, and the molar ratio among ANI, CSA and APS were 2:1:2. ANI was dissolved in $3.100 \mathrm{~g}$ of DMF with magnetic stirring at room temperature, and then $0.9 \mathrm{~g}$ of PVP and CSA were slowly added into the above solution. The mixture was then cooled down to $0{ }^{\circ} \mathrm{C}$ in an ice-bath. The mixture was denoted as solution I. A mixed solution of ammonium persulfate (APS) and $2.000 \mathrm{~g}$ of $\mathrm{DMF}$ at $0{ }^{\circ} \mathrm{C}$ was prepared as the solution II. The solution II was added dropwise into the solution I under mechanical stirring $\left(200 \mathrm{r} \cdot \mathrm{min}^{-1}\right)$. The final mixture was allowed to react at $0{ }^{\circ} \mathrm{C}$ for $24 \mathrm{~h}$ and then $\mathrm{Fe}_{3} \mathrm{O}_{4} \mathrm{NPs}$ were added into the mixture under mechanical stirring at room temperature, thus the spinning solution was prepared. The dosages of these materials were summarized in Table 1.

During the electrospinning process, a traditional electrospinning apparatus was used to prepare the $\mathrm{PANI} / \mathrm{Fe}_{3} \mathrm{O}_{4} / \mathrm{PVP}$ composite nanofibers. Spinning solution was loaded into a plastic syringe with a plastic spinneret, and
Table 1. Compositions of the spinning solutions

\begin{tabular}{ccccc}
\hline $\begin{array}{c}\text { Compositions } \\
\text { Samples }\end{array}$ & $\mathrm{ANI} / \mathrm{g}$ & $\mathbf{F e}_{\mathbf{3}} \mathbf{O}_{4} / \mathbf{g}$ & $\mathbf{C S A} / \mathbf{g}$ & $\mathbf{A P S} / \mathbf{g}$ \\
\hline S1 & 0.09 & 0.3 & 0.1123 & 0.2205 \\
S2 & 0.18 & 0.3 & 0.2245 & 0.4411 \\
S3 & 0.27 & 0.3 & 0.3367 & 0.6616 \\
S4 & 0.45 & 0.3 & 0.5612 & 1.1026 \\
S5 & 0.63 & 0.3 & 0.7857 & 1.5437 \\
S6 & 0.27 & 0.45 & 0.3367 & 0.6616 \\
S7 & 0.27 & 0.9 & 0.3367 & 0.6616 \\
S8 & 0.27 & 0.225 & 0.3367 & 0.6616 \\
\hline
\end{tabular}

the inner diameter of the spinneret was $1 \mathrm{~mm}$. Carbon rod used as anode was inserted into spinning solution. A flat iron net was used as cathode and collector and put about $11 \mathrm{~cm}$ away from the tip of the spinneret. A positive direct current (DC) voltage of $13 \mathrm{kV}$ was applied between the spinneret and the collector to generate stable, continuous PVP-based composite nanofibers under the ambient temperature of $20{ }^{\circ} \mathrm{C}-25^{\circ} \mathrm{C}$, and the relative humidity was $45 \%-50 \%$.

\subsection{Characterization Methods}

The as-prepared $\mathrm{Fe}_{3} \mathrm{O}_{4} \mathrm{NPs}$ and $\mathrm{PANI} / \mathrm{Fe}_{3} \mathrm{O}_{4} / \mathrm{PVP}$ composite nanofibers were identified by an $\mathrm{X}$-ray powder diffractometer (XRD, Bruker, D8 FOCUS) with $\mathrm{Cu} \mathrm{Ka}$ radiation. The morphology and internal structure of $\mathrm{PANI} / \mathrm{Fe}_{3} \mathrm{O}_{4} / \mathrm{PVP}$ composite nanofibers were observed by a field emission scanning electron microscope (FESEM, XL-30) and a transmission electron microscope (TEM, JEM-2010), respectively. The elementary compositions of the PANI $/ \mathrm{Fe}_{3} \mathrm{O}_{4} / \mathrm{PVP}$ nanofibers were determined by an energy dispersive X-ray spectrometer (EDX, GENESIE 2000). The electrical conductivity was detected by a Hall effect measurement system (ECOPIA HMS-3000). Then, the magnetic performances of $\mathrm{Fe}_{3} \mathrm{O}_{4} \mathrm{NPs}$ and $\mathrm{PANI} / \mathrm{Fe}_{3} \mathrm{O}_{4} / \mathrm{PVP}$ composite nanofibers were measured by a vibrating sample magnetometer (VSM, MPMS SQUID XL). All measurements were performed at room temperature in air atmosphere, and the relative humidity was $40 \%-45 \%$.

\section{Results and discussion}

\subsection{Characterizations of the Structure and Morphology}

XRD patterns of $\mathrm{Fe}_{3} \mathrm{O}_{4}$ NPs and composite nanofibers (S3) are shown in Fig. 1. The XRD patterns in Fig. 1a reveal that the as-prepared $\mathrm{Fe}_{3} \mathrm{O}_{4} \mathrm{NPs}$ are conformed to the cubic structure of $\mathrm{Fe}_{3} \mathrm{O}_{4}$ (PDF 74-0748). No characteristic diffraction peaks of any other impurities are detected. $\mathrm{XRD}$ analysis result of the $\mathrm{PANI} / \mathrm{Fe}_{3} \mathrm{O}_{4} / \mathrm{PVP}$ composite nanofibers demonstrates that the composite nanofibers contain $\mathrm{Fe}_{3} \mathrm{O}_{4}$ NPs, as indicated in Fig. $1 \mathrm{~b}$.

The morphology of the as-prepared $\mathrm{Fe}_{3} \mathrm{O}_{4}$ NPs is observed by means of TEM, as presented in Fig. 2a. The size distribution of the spherical $\mathrm{Fe}_{3} \mathrm{O}_{4} \mathrm{NPs}$ is almost uniform, and the diameter of the $\mathrm{Fe}_{3} \mathrm{O}_{4}$ NPs is $9-13 \mathrm{~nm}$. In order to characterize the size and morphology of the 
presented $\mathrm{PANI} / \mathrm{Fe}_{3} \mathrm{O}_{4} / \mathrm{PVP}$ composite nanofibers, FESEM observation is conducted. Fig. 2b shows FESEM image of $\mathrm{PANI} / \mathrm{Fe}_{3} \mathrm{O}_{4} / \mathrm{PVP}$ composite nanofibers, indicating that the as-prepared nanofibers are relatively smooth. The Image-Pro Plus 6.0 software is used to measure the diameters of the

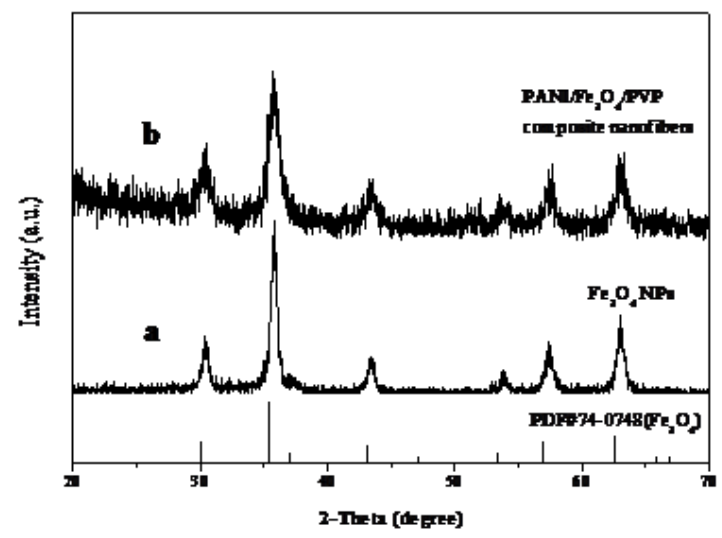

Fig. $1 \mathrm{XRD}$ patterns of $\mathrm{Fe}_{3} \mathrm{O}_{4} \mathrm{NPs}(\mathrm{a})$ and $\mathrm{PANI} / \mathrm{Fe}_{3} \mathrm{O}_{4} / \mathrm{PVP}$ composite nanofibers (b) with PDF standard card of $\mathrm{Fe}_{3} \mathrm{O}_{4}$ nanofibers, and the results are analyzed with statistics. The diameter for composite nanofibers is $400 \pm 20 \mathrm{~nm}$ under the confidence level of $95 \%$, as indicated in Fig. 3. The TEM image of $\mathrm{PANI} / \mathrm{Fe}_{3} \mathrm{O}_{4} / \mathrm{PVP}$ composite nanofibers is presented in Fig. 2c. It is obviously seen from the TEM image that $\mathrm{Fe}_{3} \mathrm{O}_{4}$ NPs are well dispersed in the composite nanofibers. A slightly agglomeration phenomenon which can be observed via FESEM and TEM is caused by the large surface energy of the nano-sized $\mathrm{Fe}_{3} \mathrm{O}_{4}$ particles. ${ }^{31}$ The EDX analysis, as shown in Fig. 2d, reveals that the composite nanofibers consist of $\mathrm{C}, \mathrm{N}, \mathrm{O}, \mathrm{S}, \mathrm{Fe}$ and $\mathrm{Au}$ elements. The Au peak in the spectrum comes from gold conductive film plated on the surface of the sample for SEM observation. No other elements are found in the sample, implying that the $\mathrm{PANI} / \mathrm{Fe}_{3} \mathrm{O}_{4} / \mathrm{PVP}$ composite nanofibers are highly pure.

\subsection{Magnetic Property}

The magnetic properties of $\mathrm{Fe}_{3} \mathrm{O}_{4} \mathrm{NPs}$ and $\mathrm{PANI} / \mathrm{Fe}_{3} \mathrm{O}_{4} / \mathrm{PVP}$ composite nanofibers are examined by a vibrating sample magnetometer. No remanence is detected for the as-prepared $\mathrm{Fe}_{3} \mathrm{O}_{4}$ NPs. The zero coercivity and the reversible hysteresis
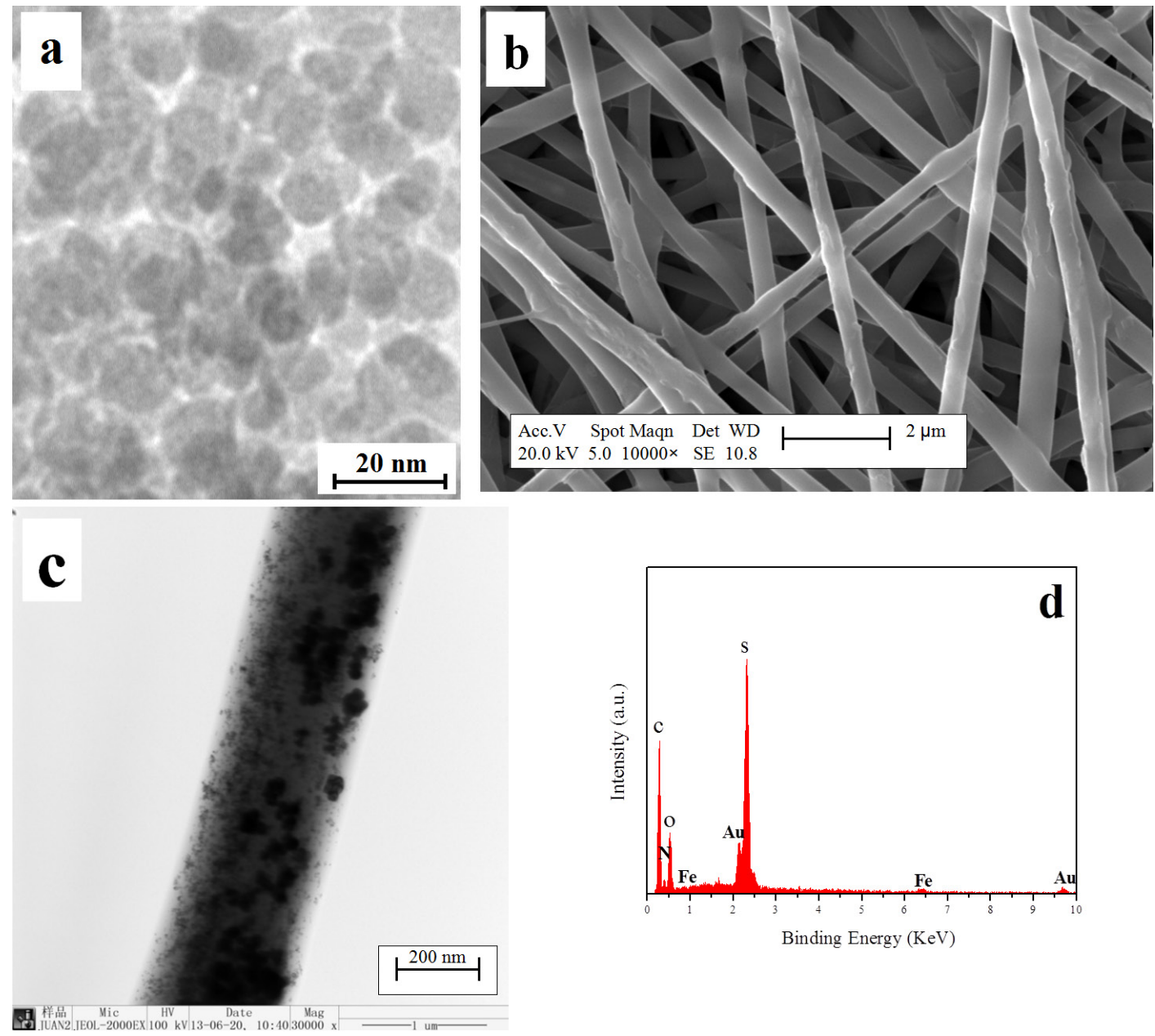

Fig. 2 TEM image (a) of $\mathrm{Fe}_{3} \mathrm{O}_{4}$ NPs and FESEM image (b), TEM image (c) and EDX spectrum (d) of PANI/Fe $\mathrm{O}_{4} / \mathrm{PVP}$ composite nanofibers 


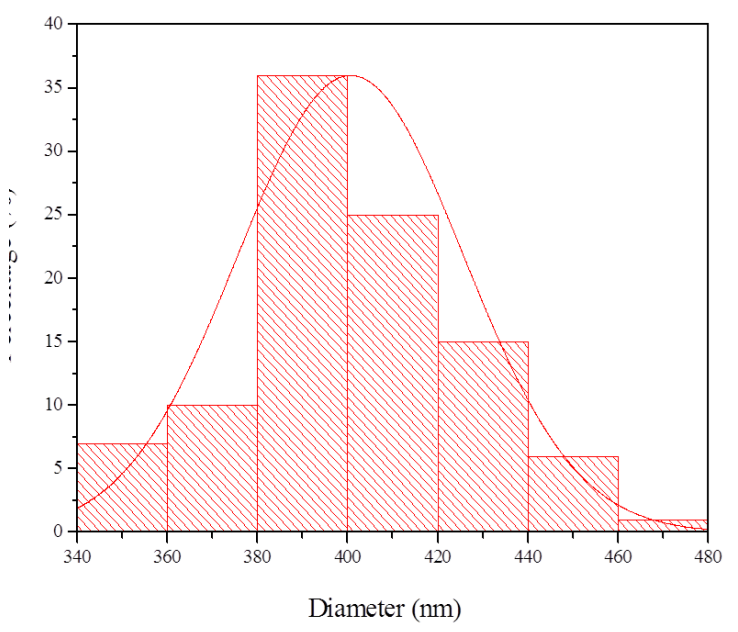

Fig. 3 Histogram of diameter distribution of $\mathrm{PANI} / \mathrm{Fe}_{3} \mathrm{O}_{4} / \mathrm{PVP}$ composite nanofibers

behavior indicate the superparamagnetic nature of the $\mathrm{Fe}_{3} \mathrm{O}_{4}$ $\mathrm{NPs},{ }^{32}$ as revealed in Fig. 4. The composite nanofibers also demonstrate superparamagnetic performance owing to $\mathrm{Fe}_{3} \mathrm{O}_{4}$ NPs introduced into the composite nanofibers. The variation of saturation magnetization value results from the different amounts of $\mathrm{Fe}_{3} \mathrm{O}_{4}$ introduced in composite nanofibers. With the increase of $\mathrm{Fe}_{3} \mathrm{O}_{4}$ content in composite nanofibers, saturation magnetization of composite nanofibers increases, as demonstrated in Fig. 4 and Table 2, implying that the magnetic properties of the composite nanofibers can be tuned via addition of various amounts of $\mathrm{Fe}_{3} \mathrm{O}_{4}$ NPs.

\subsection{Electrical Conductivity Analysis}

The average electrical conductivity values of the samples are summarized in Table 3 . The electrical conductivity is greatly increased from $1.357 \times 10^{-6}$ to $7.175 \times 10^{-3} \mathrm{~S} \cdot \mathrm{cm}^{-1}$ at the beginning when the PANI is incorporated into composite nanofibers, meaning that the electrical conductivity of the composite nanofibers can be tunable by adjusting amount of PANI. With further increase in PANI content, the electrical conductivity of composite nanofibers is only slightly increased. The increase in electrical conductivity of PANI $/ \mathrm{Fe}_{3} \mathrm{O}_{4} / \mathrm{PVP}$ composite nanofibers with increasing in PANI content is due to forming a better continuous net structure for PANI polymer. Furthermore, it is found from Table 3 that the electrical conductivity of the composite nanofibers is slightly increased with increasing in the mass ratios of $\mathrm{Fe}_{3} \mathrm{O}_{4}$ to $\mathrm{PVP}$ when fixing the other parameters, as shown in samples S3, S6, S7 and S8.

\subsection{Formation Mechanism for $\mathrm{PANI} / \mathrm{Fe}_{3} \mathrm{O}_{4} \mathrm{PVP}$ Composite Nanofibers}

We propose the formation mechanism for $\mathrm{PANI} / \mathrm{Fe}_{3} \mathrm{O}_{4} / \mathrm{PVP}$ composite nanofibers, as shown in Fig. 5. Firstly, ANI and PVP are dissolved in DMF to form solution with certain viscosity. Secondly, ammonium persulfate (APS) is added into above solution and allowed to react at $0{ }^{\circ} \mathrm{C}$ for $24 \mathrm{~h}$.

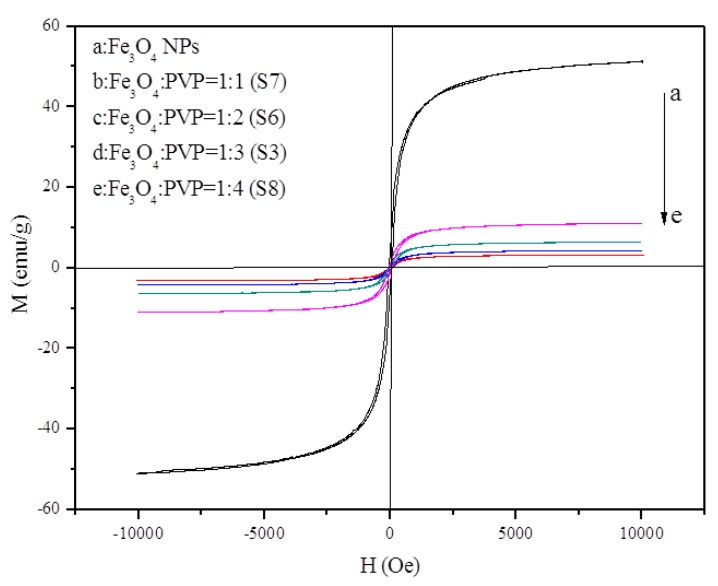

Fig. 4 Hysteresis loops of $\mathrm{Fe}_{3} \mathrm{O}_{4} \mathrm{NPs}$ (a) and PANI/Fe $\mathrm{O}_{4} / \mathrm{PVP}$ composite nanofibers with various ratios of $\mathrm{Fe}_{3} \mathrm{O}_{4}$ to $\mathrm{PVP}(\mathrm{b}, \mathrm{c}, \mathrm{d}$ and e)

Table 2 Saturation magnetization of $\mathrm{Fe}_{3} \mathrm{O}_{4} \mathrm{NPs}$ and $\mathrm{PANI} / \mathrm{Fe}_{3} \mathrm{O}_{4} / \mathrm{PVP}$ composite nanofibers

\begin{tabular}{cc}
\hline Samples & $\begin{array}{c}\text { Saturation magnetization } \\
(\mathbf{M s}) / \mathbf{e m u} \cdot \mathbf{g}^{-1}\end{array}$ \\
\hline $\mathrm{Fe}_{3} \mathrm{O}_{4} \mathrm{NPs}$ & 51.40 \\
$\mathrm{Fe}_{3} \mathrm{O}_{4}: \mathrm{PVP}=1: 1(\mathrm{~S} 7)$ & 10.90 \\
$\mathrm{Fe}_{3} \mathrm{O}_{4}: \mathrm{PVP}=1: 2(\mathrm{~S} 6)$ & 6.62 \\
$\mathrm{Fe}_{3} \mathrm{O}_{4}: \mathrm{PVP}=1: 3(\mathrm{~S} 3)$ & 4.19 \\
$\mathrm{Fe}_{3} \mathrm{O}_{4}: \mathrm{PVP}=1: 4(\mathrm{~S} 8)$ & 3.35 \\
\hline
\end{tabular}

Table 3 Electrical conductivity of the samples doped with various amount of PANI and $\mathrm{Fe}_{3} \mathrm{O}_{4} \mathrm{NPs}$

\begin{tabular}{clc}
\hline Samples & $\begin{array}{c}\text { Electrical } \\
\text { conductivity/ } \\
\text { S } \cdot \mathbf{c m}^{-1}\end{array}$ \\
\hline & $\mathrm{PANI}: \mathrm{PVP}=10 \%(\mathrm{~S} 1)$ & $1.357 \times 10^{-6}$ \\
& $\mathrm{PANI}: \mathrm{PVP}=20 \%(\mathrm{~S} 2)$ & $1.745 \times 10^{-5}$ \\
$\mathrm{Fe}_{3} \mathrm{O}_{4}: \mathrm{PVP}=1: 3$ & $\mathrm{PANI}: \mathrm{PVP}=30 \%(\mathrm{~S} 3)$ & $7.175 \times 10^{-3}$ \\
& $\mathrm{PANI}: \mathrm{PVP}=50 \%(\mathrm{~S} 4)$ & $8.666 \times 10^{-3}$ \\
& $\mathrm{PANI}: \mathrm{PVP}=70 \%(\mathrm{~S} 5)$ & $9.176 \times 10^{-3}$ \\
\hline & $\mathrm{Fe}_{3} \mathrm{O}_{4}: \mathrm{PVP}=1: 2(\mathrm{~S} 6)$ & $7.616 \times 10^{-3}$ \\
& $\mathrm{Fe}_{3} \mathrm{O}_{4}: \mathrm{PVP}=1: 1(\mathrm{~S} 7)$ & $8.167 \times 10^{-3}$ \\
& $\mathrm{Fe}_{3} \mathrm{O}_{4}: \mathrm{PVP}=1: 4(\mathrm{~S} 8)$ & $6.864 \times 10^{-3}$ \\
\hline
\end{tabular}

Finally, the prepared $\mathrm{Fe}_{3} \mathrm{O}_{4} \mathrm{NPs}$ are added into the mixture under magnetic stirring at room temperature, thus the spinning solution is prepared. The spinning solution is loaded into a plastic syringe, and then $\mathrm{PANI} / \mathrm{Fe}_{3} \mathrm{O}_{4} / \mathrm{PVP}$ composite nanofibers are fabricated by electrospinning. $\mathrm{Fe}_{3} \mathrm{O}_{4} \mathrm{NPs}$ are well dispersed in the composite nanofibers. PANI also forms a continuous network in the nanofibers, leading to high electrical conductivity of the electricity-magnetism bifunction composite nanofibers. 


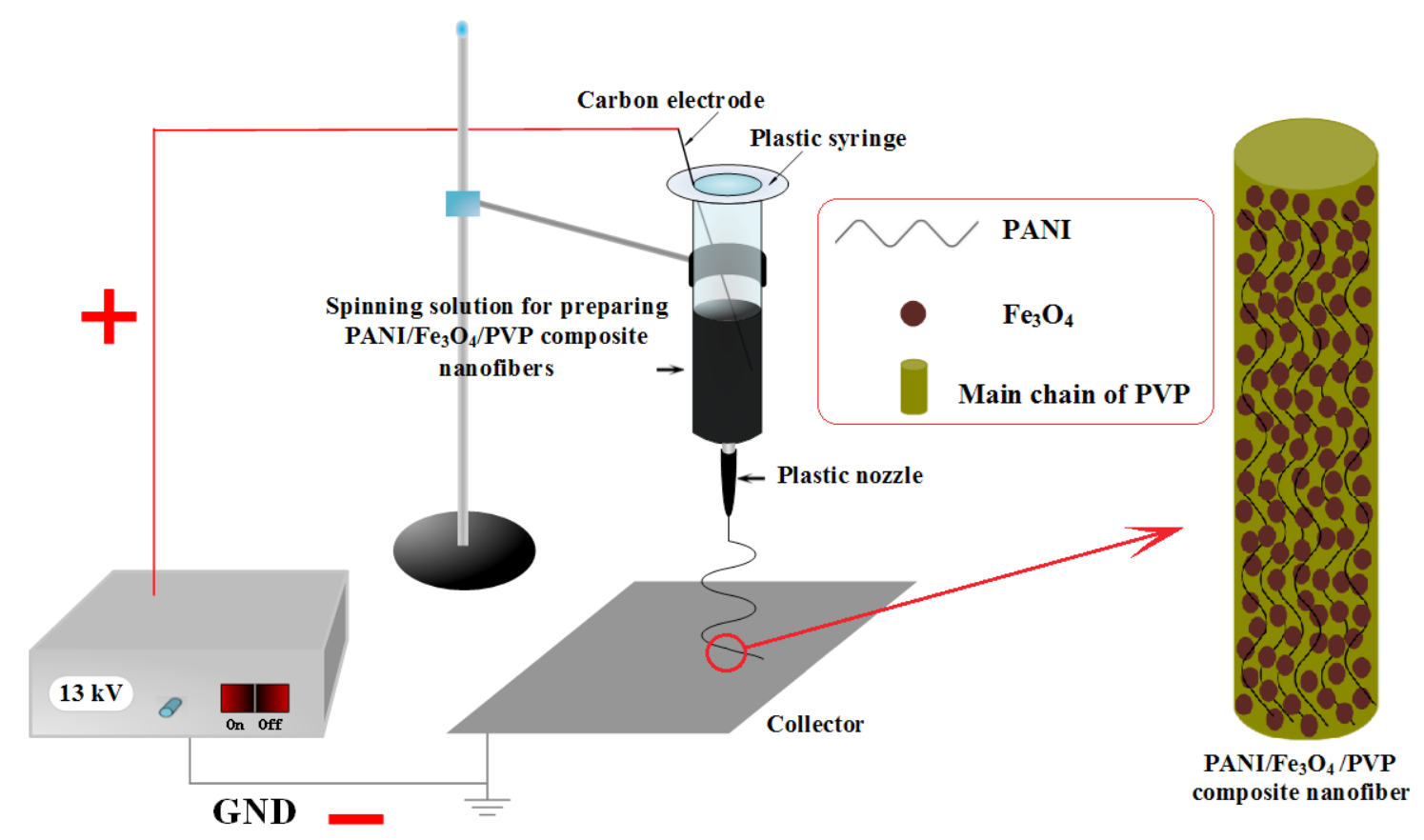

Fig. 5 Formation mechanism of $\mathrm{PANI} / \mathrm{Fe}_{3} \mathrm{O}_{4} / \mathrm{PVP}$ composite nanofibers

\section{Conclusions}

In summary, the electricity-magnetism bifunctional composite nanofibers are successfully prepared by electrospinning. Electrical conductivity and saturation magnetization of composite nanofibers can be tuned by adding different amount of PANI and $\mathrm{Fe}_{3} \mathrm{O}_{4}$ NPs into them, respectively. The composite nanofibers exhibit superparamagnetic performance and their saturation magnetizations are increased with the increase of $\mathrm{Fe}_{3} \mathrm{O}_{4}$ NPs. The best electrical conductivity of composite nanofibers reaches the order of $10^{-3} \mathrm{~S} \cdot \mathrm{cm}^{-1}$. Besides, the design conception and preparation method of the composite nanofibers are of universal significance for the fabrication of other electricity-magnetism one-dimensional nanostructures. The new electricity-magnetism bifunctional $\mathrm{PANI} / \mathrm{Fe}_{3} \mathrm{O}_{4} / \mathrm{PVP}$

\section{References}

1. Ma QL, Wang JX, Dong XT, Yu WS, Liu GX. Electrospinning fabrication of high-performance magnetic photoluminescent bifunctional coaxial nanocables. Chemical Engineering Journal. 2013; 222:16-22. doi:10.1016/j.cej.2013.02.063

2. Zhang X, Shao CL, Li XH, Lu N, Wang KX, Miao FJ, et al. $\mathrm{In}_{2} \mathrm{~S}_{3} /$ carbon nanofibers/Au ternary synergetic system: Hierarchical assembly and enhanced visible-light photocatalytic activity. Journal of Hazardous Materials. 2015; 283:599-607. doi:10.1016/j.jhazmat.2014.10.005

3. Shao DQ, Wang JX, Dong XT, Yu WS, Liu GX, Zhang F, et al. Coaxial electrospinning fabrication and electrochemical properties of $\mathrm{LiFePO}_{4} / \mathrm{C} / \mathrm{Ag}$ composite hollow nanofibers. Journal of Materials Science: Materials in Electronics. 2013;24(12):4718-4724. composite nanofibers have potential applications in many fields such as electromagnetic interference shielding, special coating, microwave absorption, molecular electronics and future nanodevices.

\section{Acknowledgments}

This work was financially supported by the National Natural Science Foundation of China (NSFC 51573023, 50972020, 51072026), Specialized Research Fund for the Doctoral Program of Higher Education (20102216110002, 20112216120003), the Science and Technology Development Planning Project of Jilin Province (Grant Nos. 20130101001JC, 20070402), the Research Project of Science and Technology of Department of Education of Jilin Province "11 th 5-year plan" (Grant Nos. 2010JYT01).

4. Sambaer W, Zatloukal M, Kimmer D. 3D modeling of filtration process via polyurethane nanofiber based nonwoven filters prepared by electrospinning process. Chemical Enginering Science. 2011;66(4):613-623.doi:10.1016/j.ces.2010.10.035

5. Corres JM, Garcia YR, Arregui FJ, Matias IR. Optical fiber humidity sensors using PVdF electrospun nanowebs. IEEE Sensor Journal. 2011;11(10):2383-2387. DOI: 10.1109/ JSEN.2011.2123881

6. Sell SA, Wolfe PS, Ericksen JJ, Simpson DG, Bowlin GL. Incorporating platelet-rich plasma into electrospun scaffolds for tissue engineering applications. Tissue Engineering. Part A. 2011;17(21-22):2723-2737. doi:10.1089/ten.tea.2010.0663.

7. Chen SL, Hou HQ, Harnisch F, Patil SA, Carmona-Martinez AA, Agarwal S, et al. Electrospun and solution blown threedimensional carbon fiber nonwovens for application as electrodes 
in microbial fuel cells. Energy \& Environmental Science. 2011; 4(4):1417-1421.

8. Zhang ZM, Li Q, Yu L, Cui ZJ, Zhang LJ, Bowmaker GA. Highly conductive polypyrrole $/ \gamma-\mathrm{Fe}_{2} \mathrm{O}_{3}$ nanospheres with good magnetic properties obtained through an improved chemical one-step method. Macromolecules. 2011;44(12):4610-4615. DOI: $10.1021 / \mathrm{ma} 2006359$

9. Virji S, Fowler JD, Baker CO, Huang JX, Kaner RB, Weiler BH. Polyaniline nanofiber composites with metal salts: chemical sensors for hydrogen sulfide. Small 2005; 1(6):624-627. DOI: 10.1002/smll.200400155

10. Zhang QH, Jin HF, Wang XH, Jing XB. Morphology of conductive blend fibers of polyaniline and polyamide-11. Synthetic Metals. 2001;123(3):481-485. doi:10.1016/S0379-6779(01)00354-X

11. Huang JX, Virji S, Weiller BH, Kaner RB. Nanostructured polyaniline sensors. Chemistry-A European JournaL. 2004;10(6):1314-1319. DOI: 10.1002/chem.200305211

12. Yu QZ, Shi MM, Deng M, Wang M, Chen HZ, et al. Morphology and conductivity of polyaniline sub-micron fibers prepared by electrospinning. Materials Science and Engineering $B$. 2008;150(1):70-76.doi:10.1016/j.mseb.2008.02.008

13. Chabert F, Dunstan DE, Franks GV. Cross-linked polyvinyl alcohol as a binder for gelcasting and green machining. Journal of the American Ceramic Society. 2008; 91(10):3138-3146. DOI: 10.1111/j.1551-2916.2008.02534.x

14. Ballengee JB, Pintauro PN. Morphological control of electrospun Nafion nanofiber mats. Journal of the Electrochemical Society. 2011;158:B568-572.

15. Tang DS, Xie SS, Pan ZW, Sun LF, Liu ZQ, Zou XP, et al. Preparation of monodispersed multi-walled carbon nanotubes in chemical vapor deposition. Chemical Physics Letters. 2002;356(5):563-566. doi:10.1016/S0009-2614(02)00413-X

16. Wiltshire MC, Pendry JB, Young IR, Larkman DJ, Gilderdale DJ, Hajnal JV. Microstructured magnetic materials for RF flux guides in magnetic resonance imaging. Science. 2001;291(5505):849851.

17. Trivedi P, Axe L. Modeling Cd and $\mathrm{Zn}$ sorption to hydrous metal oxides. Environmental Scienc \& Technology. 2000;34(11):2215-2223.

18. Bucak S, Jones DA, Laibinis PE. Protein separations using colloidal magnetic nanoparticles. Biotechnology Progress. 2003;19:477-484.

19. Kolotilov SV, Cador O, Pointillart F, Golhen S, Le Gai Y, Gavrilenko KS, Ouahab L. A new approach towards ferromagnetic conducting materials based on TTF-containing polynuclear complexes. Journal of Materials Chemistry. 2010;20(42):95059514. DOI: 10.1039/B925178B

20. Balan BK, Kale VS, Aher PP, Shelke MV, Pillai VK, Kurungot $\mathrm{S}$. High aspect ratio nanoscale multifunctional materials derived from hollow carbon nanofiber by polymer insertion and metal decoration. Chemical Communications. 2010; 46(30):5590-5592.
21. Bi F, Dong XT, Wang JX, Liu GX. Tuned magnetism-luminescence bifunctionality simultaneously assembled into flexible Janus nanofiber. RSC Advances. 2015; (5917):12571-12577. DOI: 10.1039/C4RA10022K

22. Lu P, Zhang JL, Liu YL, Sun DH, Liu GX, Hong GY, Ni JZ. Synthesis and characteristic of the $\mathrm{Fe}_{3} \mathrm{O}_{4} @ \mathrm{SiO}_{2} @ \mathrm{Eu}(\mathrm{DBM})_{3} \cdot 2 \mathrm{H}_{2} \mathrm{O} /$ $\mathrm{SiO}_{2}$ luminomagnetic microspheres with core-shell structure. Talanta. 2010;83:450-457.

23. Peng HX, Liu GX, Dong XT, Wang JX, Yu WS, Xu J. Magnetic, luminescent and core-shell structured $\mathrm{Fe}_{3} \mathrm{O}_{4} @ \mathrm{YF}_{3}: \mathrm{Ce}^{3+}, \mathrm{Tb}^{3+}$ bifunctional nanocomposites. Powder Technology. 2012;215216:242-246.doi:10.1016/j.powtec.2011.10.006

24. Wang W, Zou M, Chen KZ. Novel $\mathrm{Fe}_{3} \mathrm{O}_{4} @ \mathrm{YPO}_{4}$ : Re $(\mathrm{Re}=$ $\mathrm{Tb}, \mathrm{Eu})$ multifunctional magnetic-fluorescent hybrid spheres for biomedical applications. Chemical Communications. 2010; 46(28):5100-5102. DOI: 10.1039/C0CC00262C

25. Ma QL, Yu WS, Dong XT, Wang JX, Liu GX, Xu J. Electrospinning preparation and properties of $\mathrm{Fe}_{3} \mathrm{O}_{4} / \mathrm{Eu}(\mathrm{BA})_{3}$ phen/PVP magneticphotoluminescent bifunctional composite nanofibers. Journal of Nanoparticle Research. 2012;14(10):1203-1209.

26. Ma QL, Yu WS, Dong XT, Wang JX, Liu GX, Xu J. Electrospinning fabrication and properties of $\mathrm{Fe}_{3} \mathrm{O}_{4} / \mathrm{Eu}(\mathrm{BA})_{3}$ phen/PMMA magneticphotoluminescent bifunctional composite nanoribbons. Optical Materials. 2013;35(3):526-530. doi:10.1016/j.optmat.2012.10.004

27. Ma QL, Wang JX, Dong XT, Yu WS, Liu GX. Fabrication of magnetic-fluorescent bifunctional flexible coaxial nanobelts by electrospinning using a modified coaxial spinneret. ChemPlusChem. 2014;79(2):290-297.

28. Ma QL, Yu WS, Dong XT, Wang JX, Liu GX. Janus nanobelts: fabrication, structure and enhanced magnetic-fluorescent bifunctional performance. Nanoscale. 2014; 6(5):2945-2952. DOI: $10.1039 / \mathrm{C} 3 \mathrm{NR} 05472 \mathrm{~A}$

29. Ma QL, Wang JX, Dong XT, Yu WS, Liu GX, Xu J. Electrospinning preparation and properties of magnetic-photoluminescent bifunctional coaxial nanofibers. Journal of Materials Chemistry. 2012;22(29):14438-14442. DOI: 10.1039/C2JM32043F

30. Wang YH, Wang JX, Dong XT, Yu WS, Liu GX. Electrospinning preparation and properties of $\mathrm{Eu}(\mathrm{BA})_{3}$ phen/PANI/PVP luminescence-electricity bifunctional composite nanofibers. Chemical Journal of Chinese Universities. 2012;8:1657-1662.

31. Zhu YF, Zhao WR, Chen HR, Shi JL. A simple one-pot selfassembly route to nanoporous and monodispersed $\mathrm{Fe}_{3} \mathrm{O}_{4}$ particles with oriented attachment structure and magnetic property. Journal of Physical Chemistry. 2007;111(14):5281-5285. DOI: 10.1021/jp0676843

32. Xuan SH, Hao LY, Jiang WQ, Gong XL, Hu Y, Chen ZY. Preparation of water-soluble magnetite nanocrystals through hydrothermal approach. Journal of Magnetism and Magnetic Materials. 2007;308(2):210-213. doi:10.1016/j.jmmm.2006.05.017 